\title{
Rевевсн автісіе: Effect of dose and time of application of phosphorus on changes in phosphorus uptake pattern and yield of rice grown on $\mathrm{P}$ accumulated soil
}

\author{
K. ARCHANA, T. PRABHAKAR REDDY, T. ANJAIAH AND B. PADMAJA
}

Article Chronicle : Received :

11.07.2017;

Accepted :

26.07.2017

KEY Words:

Time of application,

Changes,

Phosphorus uptake Yield of rice grown, $P$ accumulated soil

Author for correspondence :

\section{K. ARCHANA}

Department of Soil

Science and Agricultural

Chemistry, Agricultural

College, PJTSAU,

Polasa, Jagtial,

KARIMNAGAR

(TELANGANA) INDIA

See end of the article for

authors' affiliations
SUMMARY : A survey was carried out during May, 2015 from 50 rice growing farmers to identify the farmer's practice of dose and time of $\mathrm{P}$ application. Based on the survey data, the average of 50 farmers $\mathrm{P}$ fertilizer dose $\left(85 \mathrm{~kg} \mathrm{P}_{2} \mathrm{O}_{5} \mathrm{ha}^{-1}\right)$ was fixed as $100 \%$ farmer's dose and majority of the farmers practice i.e. two equal splits at basal and at top dressing at early tillering stage (14 to $20 \mathrm{DAT}$ ) was decided as farmer practice of splitsfor conducting field experiment on rice in $\mathrm{P}$ accumulated soil. The field experiment was consisting of twelve treatment combinations with six levels of phosphorus $(100,75$ and $50 \%$ farmers dose and 100, 75 and 50 \% RDP) and its time of application (Farmer practice of split application and basal application). As part of this investigation, The crop has given good response to application of $100 \%$ farmers dose of $\mathrm{P}\left(85 \mathrm{~kg} \mathrm{P}_{2} \mathrm{O}_{5} \mathrm{ha}^{-1}\right)$ but at the same time which was found to be on par with the application of $100 \% \operatorname{RDP}\left(60 \mathrm{~kg} \mathrm{P}_{2} \mathrm{O}_{5} \mathrm{ha}^{-1}\right), 75 \%$ farmers dose $\left(64 \mathrm{~kg} \mathrm{P}_{2} \mathrm{O}_{5} \mathrm{ha}^{-1}\right)$ and $75 \% \mathrm{RDP}\left(45 \mathrm{~kg} \mathrm{P}_{2} \mathrm{O}_{5}\right.$ $\left.\mathrm{ha}^{-1}\right)$. This can be inferred as saving of $\mathrm{P}$ fertilizer to rice from current recommended dose and farmer's dose in soils having higher initial available $\mathrm{P}$. With respect to time of $\mathrm{P}$ application, $\mathrm{P}$ uptake by the grain was significantly higher in split application than the treatment receiving basal $\mathrm{P}$, although this had no significant influence on the increase in grain yield of rice.

How to cite this article : Archana, K., Reddy, T. Prabhakar, Anjaiah, T. and Padmaja, B. (2017). Effect of dose and time of application of phosphorus on changes in phosphorus uptake pattern and yield of rice grown on $\mathrm{P}$ accumulated soil. Agric. Update, 12 (TECHSEAR-4): 960-965; DOI: 10.15740/HAS/AU/12.TECHSEAR (4)2017/ 960-965. 